One limitation of the work is that it is confined almost exclusively to the strictly economic aspects of Soviet and East European societies. This may seem like a strange and unjustified criticism of a book whose explicit concern is with the "Socialist Economies of the Soviet Union and Europe." But it is precisely because of the ambitious nature of this undertaking that the criticism seems worth offering. Any attempt to describe and analyze the workings of an economic "system" as a whole-especially a nonmarket system in most of its variantsrequires some identification of the political structures and social groups directing the operation of the economy. I am not suggesting that Lavigne's book would have gained from a simple recitation of familiar facts about Party and State. A study of the "political economy" of socialist societies does require, however, the readiness to draw on a variety of social science disciplines.

Finally, American readers should be challenged by Lavigne's comparatively positive evaluation of socialist foreign aid policies, as well as her argument that the frequently inefficient use of labor in socialist societies "is of secondary importance" when seen in the perspective of the achievement of "the right to work"except in Yugoslavia.

MURRay Yanowitch Hofstra University

THE REVOLUTIONARY PARTY: ESSAYS IN THE SOCIOLOGY OF POLITICS. By Feliks Gross. Westport, Conn. and London: Greenwood Press, 1974. xx, 280 pp. $\$ 13.95$.

In this book Professor Gross has brought together several previously published pieces on such diverse subjects as political assassinations, dress, rituals and political mythmaking, the sociology of international relations, and underground movements. He fits the material into a framework of three introductory chapters: early concepts of the political party, the origins of the centralistic and revolutionary party, and, finally, the dynamics of a political party.

No other author has successfully encompassed such a diversity of political groups, and I am afraid that Professor Gross has not advanced the cause of a general theory of parties much either. $\mathrm{He}$ is very sensitive to the interdependence of such variables as ideology, the socioeconomic environment, the party structure, and its strategies and tactics, but he tends not to get very far beyond the fact of interdependence. What one wants to know is how ideology affects structure, how tactics affect ideology, and so on. What we get instead are classificatory schemes: types of political parties, types of underground movements, kinds of political assassination, and ultimately a checklist of all of the things one might look at in studying a political movenent. Given the complexity of politics, it is the analyst's task to begin paring down the explanatory variables, a task made necessary by the scope of the phenomena to be explained.

More useful are the author's analyses of specific types of political action such as underground movements and political assassination. The essay on underground movements draws heavily on Polish and Eastern European experience, particularly during the war. But again Professor Gross tends to overexpand the discussion-including such (once) topical subjects as the "underground" movement in the United States during the 1960s, which, as he points out, was under- 
ground in none of the senses applied to its European forebears. While the book may be weak in providing general explanations of political phenomena it nevertheless is a good addition to our knowledge of some specific forms of organization.

JOSEPH A. SCHLESINGER

Michigan State University

\section{THE SOVIET WEST: INTERPLAY BETWEEN NATIONALITY AND SOCIAL ORGANIZATION. Edited by Ralph $S$. Clem. Foreword by Edward Allrworth. New York: Praeger Publishers, 1975. xvi, 161 pp. $\$ 15.00$.}

Soviet nationality policy, while permitting some forms of national expression, uses socioeconomic and political pressures to encourage national groups to integrate with the Soviet polity. The Soviet West, which includes the republics of Estonia, Latvia, Lithuania, Belorussia, the Ukraine, and Moldavia, is an area of major political and economic importance to the Soviet Union, as well as an area with traditional ties to Europe and with a record of national dissent. Thus, it is an area of special interest for exanining the effectiveness of Soviet nationality policy.

This collection of articles focuses on the interaction between the efforts of national groups to preserve their identities and the pressures for integration from the Party, the press, the schools, and the economy. Each author, drawing extensively from a review of the local Soviet press, examines one aspect of this interaction in one republic and seeks to discover a pattern of development common to the Soviet West as a whole. The various studies reveal both indifference and resistance to campaigns and policies aimed at promoting integration. The general picture which emerges is that, despite pressures for integration, national identity remains strong, has in some cases increased during the Soviet period, and remains a potentially disruptive force throughout the Soviet West.

These papers grew out of the graduate seminar in Soviet nationality problems at Columbia University and are published as part of the Praeger Special Studies program. They are of interest mainly to the specialist. As with any collection the quality of the writing and analysis is uneven. Some of the contributions are poorly organized and some of the authors draw rather broad conclusions from little evidence. However, as a whole, the work offers much new and revealing information, and thus contributes to a better understanding of the Soviet nationality problem.

\section{Catharine V. Ewing} Phillips University

\section{REHUMANIZATION OR DEHUMANIZATION ?: PHILOSOPHICAL ESSAYS ON CURRENT ISSUES OF MARXIST HUMANISM. By Pavel Kovaly. Boston: Branden Press, 1974. 153 pp. $\$ 8.75$.}

The five essays which make up this volume were previously published in Studies in Soviet Thought from April 1971 to June 1973. To these have been added a brief introduction, a two-page postscript, and a brief bibliography on Solzhenitsyn. Four of the essays deal with Arnost Kolman, György Lukács, Adam Schaff, and Alexander Solzhenitsyn respectively. The fifth addresses the question "Is It Possible to Humanize Marxism?" The main thesis, which is suggested rather 